\title{
Analysis of A Tall Building with Shear Wall of RCC and Steel Plate
}

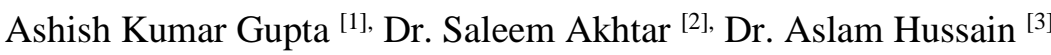 \\ ${ }^{[1]}$ Student of ME Structural Engineering, Department of Civil Engineering \\ ${ }^{\text {[2] }}$ Prof. Department of Civil Engineering \\ ${ }^{[3]}$ Assistant Prof. Department of Civil Engineering \\ University Institute Of Technology, \\ Rajiv Gandhi Proudyogiki Vishwavidyalaya, Bhopal, (M.P.)
}

\begin{abstract}
Absrtract:- Tall Structures are most influenced by lateral forces in seismic prone areas. The most significant basis to be considered in the design of the tall structures is to oppose lateral forces which can cause instability and sudden failure of the structure. In this manner it is necessitated that structure ought to have enough lateral stability to oppose lateral forces and to control the lateral displacement of the building. The shear wall is one of the most generally utilized lateral loads opposing System in elevated structures Shear wall has high in-plane stiffness and quality which can be utilized to all the while opposing enormous horizontal loads and support gravity loads. The incorporation of the Shear wall has turned out to be inescapable in multi-storeys working to oppose lateral forces. It is exceptionally important to decide the successful, effective and ideal location of the shear wall. In this paper, seismic analysis has been done on G+ 10 storeys building in Zone IV. The analysis has been done considering shear wall of RCC and steel plate. Parameters like axial load, displacement, Overturning moment, stiffness etc. are determined for different location of shear wall.
\end{abstract}

Keywords - Shear wall, Seismic loading, lateral loading

\section{INTRODUCTION}

The basic role of all kinds of structural systems utilized in a building type structures is to support gravity loads. The most widely recognized loads resulting from the impact of gravity are dead load, live load and snow load. Other than these vertical loads, buildings are likewise exposed to lateral loads brought about by the wind, impact load or seismic tremors. Following are the various structural systems:

1. Structural frame systems: the structural system comprises of frames. Floor slabs, beams, and columns are the essential components of the structural system. Such frames can carry gravity loads while giving satisfactory stiffness.

2. Structural wall systems: in this kind of structures, all the vertical members are made of structural walls, generally called shear walls.

3. Shear wall-frame systems (double systems): the system comprises of reinforced Concrete frames interacting with reinforced concrete shear walls.

Shear wall is a structural part in a reinforced concrete framed structure to oppose lateral forces, for example, wind forces. Shear walls are commonly utilized in tall structures subject to the lateral breeze and seismic forces. In reinforced concrete framed structures the impact of wind forces increase as the height of the structure increases.

1.1 LITERATURE REVIEW

\begin{tabular}{|c|c|c|c|}
\hline Author name & Name of Journal & Title name & Research finding \\
\hline $\begin{array}{c}\text { Peter Timler et al. } \\
(\mathbf{1 9 9 8})^{\mathbf{1}}\end{array}$ & $\begin{array}{c}\text { The Structural Design of Tall } \\
\text { Buildings, 1998 } \\
\text { Volume-7, PP. 233-249 }\end{array}$ & $\begin{array}{c}\text { Experimental and } \\
\text { analytical studies of steel } \\
\text { plate shear walls as applied } \\
\text { to the design of tall } \\
\text { buildings }\end{array}$ & $\begin{array}{c}\text { In this study, three variations of a steel framed office } \\
\text { building were used as case studies. Competitive } \\
\text { reinforced concrete designs were also performed for } \\
\text { economic comparisons. }\end{array}$ \\
\hline Astaneh-Asl (2001) & $\begin{array}{c}\text { SEAONC Seminar, November } \\
\text { 2001, San Francisco. PP. 1-18 }\end{array}$ & $\begin{array}{c}\text { Seismic Behaviour and } \\
\text { Design of Steel Shear } \\
\text { Walls }\end{array}$ & $\begin{array}{c}\text { Seismic design of steel shear walls including } \\
\text { provisions on } \\
\text { how to establish strength of the wall as well as } \\
\text { provisions on detailing to ensure sufficient ductility } \\
\text { are made. }\end{array}$ \\
\hline Burcu Burak (2013) & $\begin{array}{c}\text { Journal of Structural Engineering } \\
\text { 2013, Volume-139, PP. 1928- } \\
1937 .\end{array}$ & $\begin{array}{c}\text { Effect of shear wall area to } \\
\text { floor area ratio on the } \\
\text { seismic behaviour of } \\
\text { reinforced concrete } \\
\text { buildings }\end{array}$ & $\begin{array}{c}\text { The results obtained from the nonlinear time history } \\
\text { analyses including roof drift, inter story drift, and the } \\
\text { base shear responses are evaluated to obtain the } \\
\text { effect of shear wall area to floor area ratio on the } \\
\text { seismic performance of RC buildings that have no } \\
\text { torsional irregularities. }\end{array}$ \\
\hline
\end{tabular}




\begin{tabular}{|c|c|c|c|}
\hline Sumit Pawah (2014) & $\begin{array}{c}\text { International Journal of } \\
\text { Emerging Technology and } \\
\text { Advanced Engineering } \\
\text { (IJETAE), 2014, } \\
\text { PP. 244- 252 }\end{array}$ & $\begin{array}{c}\text { steel plate shear wall - a } \\
\text { lateral load resisting } \\
\text { system }\end{array}$ & $\begin{array}{c}\text { Provision of part shear walls in zone V is not enough } \\
\text { to keep maximum displacements within permissible } \\
\text { limits, whether it is a beam slab framed structure or } \\
\text { framed structure with flat slabs with drop. }\end{array}$ \\
$\begin{array}{c}\text { R.Resmi and S.Yamini } \\
\text { Roja (2016) }\end{array}$ & $\begin{array}{c}\text { International Journal of } \\
\text { Applied Engineering } \\
\text { Research, 2016, ISSN NO. } \\
\text { 0973-4562 Vol. 11 No.3, } \\
\text { PP. 369-370 }\end{array}$ & $\begin{array}{c}\text { A review on performance } \\
\text { of shear wall }\end{array}$ & $\begin{array}{c}\text { Shear wall provided along the periphery of the } \\
\text { structure is found to be more effective. }\end{array}$ \\
& & & \\
& & & \\
& &
\end{tabular}

\subsection{OBJECTIVES OF THE PRESENT STUDY}

1. To prepare 3D model of a tall building for detailed analysis.

2. To perform analysis of a tall building without shear wall.

3. To perform analysis of the tall building using RCC shear wall.

4. To perform analysis of the tall building using steel plate shear wall.

5. To compare the results of analysis of the tall building with and without shear walls.

6. To draw suitable conclusion from the above analysis.

\subsection{SCOPE OF STUDY}

The accuracy and the ability of the proposed structure are tested by static lateral load analysis in shear wall-frame system. In order to check the validity of the proposed models are executed on taken into consideration structural systems, in which shear walls are modelled via wall factors of ETABS [2015]. This analysis of lateral load resisting members in a building will assist us to increase the stability of structure against displacement and to decreases bending moment in vertical members (column).

\section{METHODOLOGY}

Table 1. Description of member used

\begin{tabular}{|l|c|c|}
\hline & RCC Frame & Steel Frame \\
\hline Design data of building & Dimension & Dimension \\
\hline Plan dimension & $25 \mathrm{~m} * 25 \mathrm{~m}$ & $5 \mathrm{~m} * 25 \mathrm{~m}$ \\
\hline No. of bay X-direction & $5 \mathrm{Bay}$ & $5 \mathrm{Bay}$ \\
No. of bay Y-direction & $5 \mathrm{Bay}$ & $\mathrm{G}+10$ \\
\hline No. of storey & $\mathrm{G}+10$ & $3000 \mathrm{~mm}$ \\
\hline Typical storey height & $3000 \mathrm{~mm}$ & $3000 \mathrm{~mm}$ \\
\hline Bottom storey height & $3000 \mathrm{~mm}$ & ISHB400-2(auto selected) \\
\hline Size of column & $800 * 800($ auto selected) & ISHB400-2(auto selected) \\
\hline Size of beam & $200 * 600($ auto selected) & $200 \mathrm{~mm}$ \\
\hline Thickness of slab & $200 \mathrm{~mm}$ & $200 \mathrm{~mm}$ (steel plate shear wall) \\
\hline Thickness of shear wall & $200 \mathrm{~mm}$ (concrete Shear wall) & \\
\hline
\end{tabular}

Table 2. Material property

\begin{tabular}{|c|c|c|}
\hline Material & Concrete Frame & Steel Frame \\
\hline Concrete & M-30 & HYSD500 \\
\hline Steel & HYSD500 & HYSD500 \\
\hline Shear Wall
\end{tabular}

\subsection{STEPS FOR ANALYSIS AND DESIGN OF STRUCTURAL ELEMENTS}

1. We choose Indian code for design.

Etabs>file>new model>use built -in setting with>set (display unit, steel design code, concrete code section database)

2. Selection of Grid Plan. No. of Grid Lines in $\mathrm{X}$ and Y-Direction are 5. Spacing in $\mathrm{X}$ and Y-Direction is 5m. No. Of Storeys in Building are 10. Height of typical Storey and Bottom Storey is $3 \mathrm{~m}$.

3. Selection of grid dimensions and defining the material properties of the building section.

Define>Material Properties>Add New Material $>$ Material Properties Data

4. Defining material properties and section properties of the building section.

Define $>$ sectional properties $>$ frame section $>$ frame properties $>$ add new properties $>$ choose concrete $>$ frame section properties data

5. Defining the slab properties of the building section.

Define>sectional properties>slabs properties>slabs properties data 
6. Selection of beam and column section from toolbar, draw the building frame section.

Quick draw beam>properties of beam section>select beam properties> draw the beam>Quick draw column>properties of column section>select column properties $>$ draw the column>Quick draw slab $>$ properties of slabs $>$ select the slabs properties $>$ draw the slab

7. Drawing the wall of the building.

Quick Draw wall> properties of wall section>select wall properties> draw the wall

8. Designing the shear wall.

Wall of the building $>$ assign $>$ shell $>$ pier label $>$ choose $>$ P1 $>$ apply $>$ select wall of building $>$ assign $>$ shell $>$ spandrel label>choose $\mathrm{S} 1>$ select wall of building>assign $>$ shell $>$ wall auto mesh option>shell assignment wall auto mesh option>advanced modify/auto mesh rectangular>select wall of building>assigning the load

\section{THREE-DIMENSIONAL MODELING FOR ANALYSIS}

The following eight models are taken for analysis purpose:

Model 1: In this model, no shear wall has been provided at the concrete frame building.

Model 2: In this model, the Concrete Shear wall has been provided at the corners of the buildings.

Model 3: In this model, the Concrete shear wall has been provided at the corner of the R.C.C building in the tubular form throughout ten storeys.

Model 4: In this model, the concrete shear wall has been provided at the middle (tubular form) and at the corners of the R.C.C building throughout ten storeys.

Model 5: In this model, no shear wall has been provided at steel frame building.

Model 6: In this model, the steel plate shear wall has been provided at the corner of the steel building.

Model 7: In this model, the steel plate shear wall has been provided at the corner of the building in the tubular form.

Model 8: In this model, the steel plate shear wall has been provided at the middle (tubular form) and corner of the building.

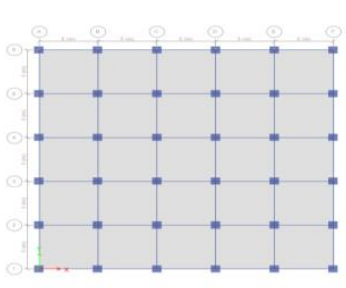

Plan

MODEL-1
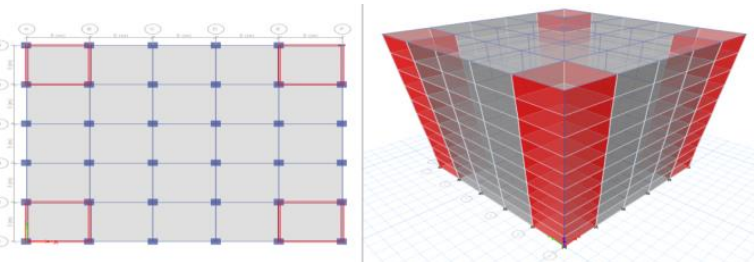

Plan

Elevation

MODEL-3

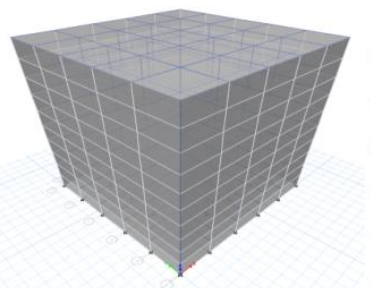

Elevation

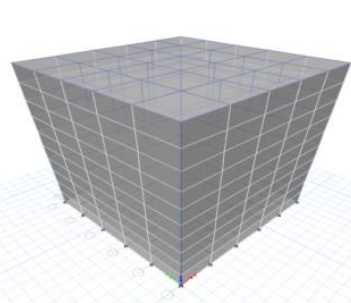

Plan

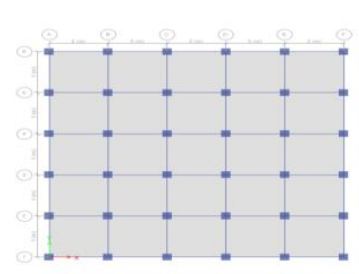

Elevation

MODEL-5
Plan

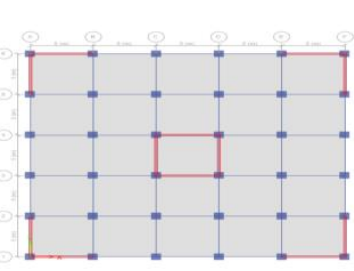

Plan
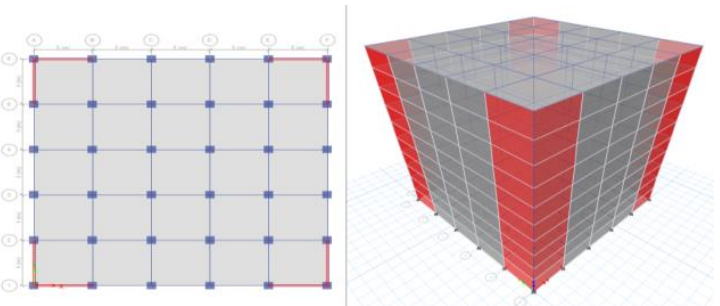

Elevation

MODEL-2

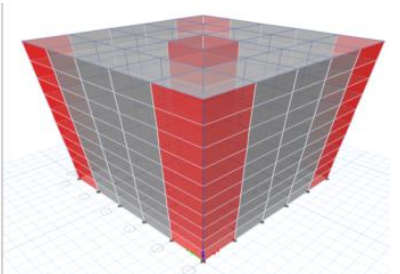

Elevation

MODEL-4

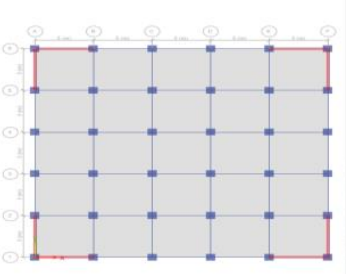

Plan

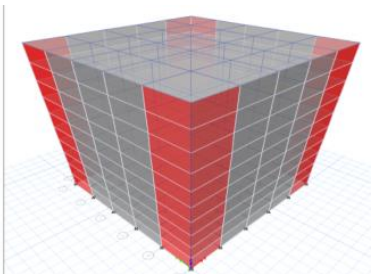

Elevation

MODEL-6 


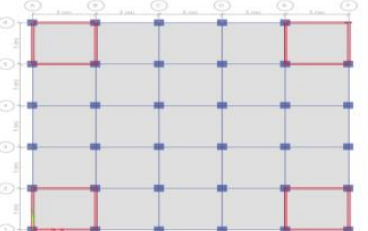

Plan

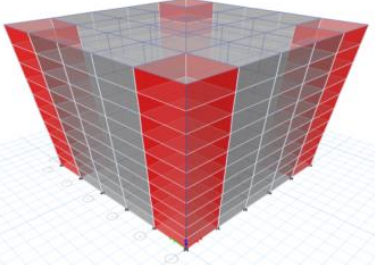

Elevation

MODEL-7

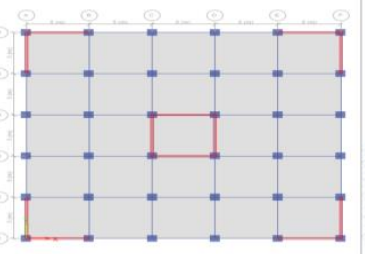

Plan

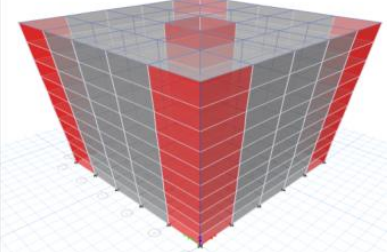

Elevation

MODEL-8

\section{ANALYSIS AND RESULTS}

Structural analysis is done for all the eight models. Parameters obtained through analysis include maximum storey deflection, maximum storey drift, storey shear, overturning moments generated while applying earthquake load on the structure. Results are shown below in tabular and graphical form.

\subsection{MAXIMUM STOREY DISPLACEMENT}

The values of maximum storey displacement, as mentioned in IS 1893(part 1): 2002, for various models are given below.

Table 3. Maximum storey displacement ( $\mathrm{mm})$

\begin{tabular}{|l|c|c|c|c|c|c|c|c|}
\hline \multicolumn{1}{|c|}{ Storey } & Model1 & Model2 & Model3 & Model4 & Model5 & Model6 & Model7 & Model8 \\
\hline Storey10 & 25.95 & 25.816 & 25.239 & 21.24 & 13.005 & 9.959 & 8.949 & 7.738 \\
\hline Storey9 & 24.827 & 24.713 & 24.155 & 20.179 & 11.68 & 8.884 & 7.938 & 7.227 \\
\hline Storey8 & 23.058 & 22.966 & 22.437 & 18.682 & 10.161 & 7.7 & 6.838 & 6.484 \\
\hline Storey7 & 20.773 & 20.701 & 20.213 & 16.737 & 8.566 & 6.476 & 5.715 & 5.605 \\
\hline Storey6 & 18.102 & 18.05 & 17.613 & 14.407 & 6.954 & 5.243 & 4.597 & 4.667 \\
\hline Storey5 & 15.162 & 15.126 & 14.75 & 11.786 & 5.367 & 4.036 & 3.516 & 3.725 \\
\hline Storey4 & 12.051 & 12.029 & 11.721 & 8.98 & 3.862 & 2.897 & 2.507 & 2.819 \\
\hline Storey3 & 8.852 & 8.841 & 8.606 & 6.115 & 2.496 & 1.87 & 1.608 & 1.974 \\
\hline Storey2 & 5.632 & 5.63 & 5.473 & 3.373 & 1.337 & 1.007 & 0.858 & 1.202 \\
\hline Storey1 & 2.577 & 2.478 & 2.399 & 1.092 & 0.468 & 0.356 & 0.301 & 0.509 \\
\hline Base & 0 & 0 & 0 & 0 & 0 & 0 & 0 & 0 \\
\hline
\end{tabular}

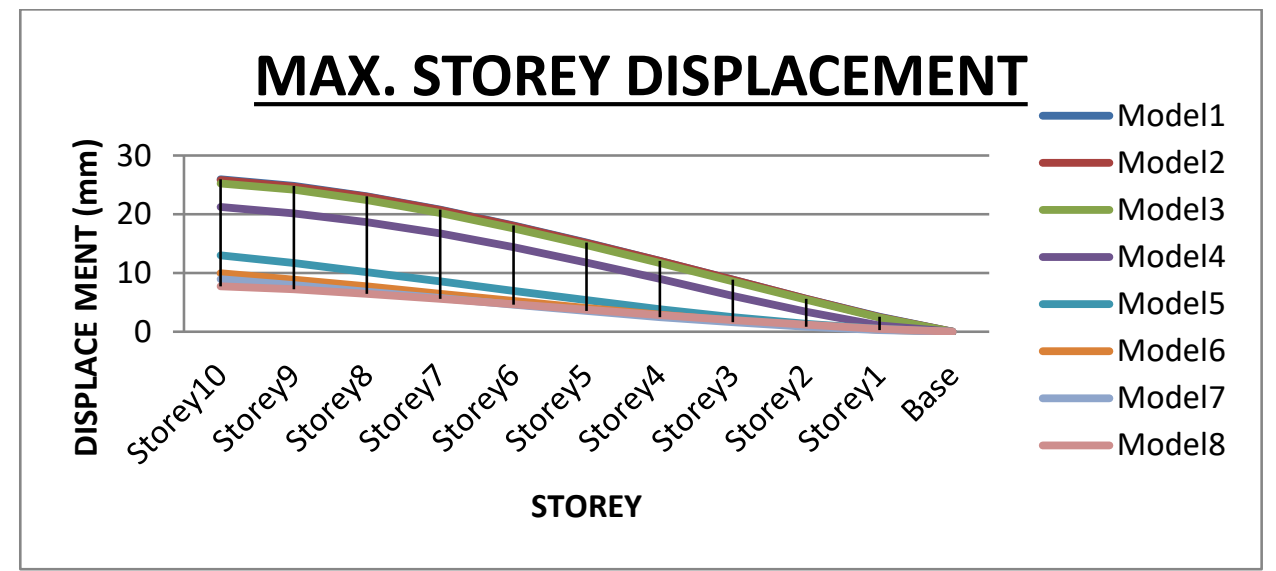

Figure 1. Maximum Storey Displacement at different storeys for various models

Comparing all the models, it has been found that the highest displacement value occurred at the 10th storey in model-1 \& lowest value in model-8. The value of displacement increases with height, There is abrupt reduction in the values of displacement, as shown in the table 3 due to the replacement of concrete shear wall with the steel plate shear wall (SPSW).

\subsection{MAXIMUM STOREY DRIFT}

The values of maximum storey drift obtained for various models after analysis, as per IS 1893(part 1): 2002, are given in table 5 and shown graphically in figure 3 . 
Table 4. Maximum storey drifts (mm)

\begin{tabular}{|c|c|c|c|c|c|c|c|c|}
\hline Storey & Model1 & Model2 & Model3 & Model4 & Model5 & Model6 & Model7 & Model8 \\
\hline Storey10 & 0.000356 & 0.000479 & 0.000352 & 0.000374 & 0.000367 & 0.000362 & 0.000391 & 0.000360 \\
\hline Storey9 & 0.000499 & 0.000507 & 0.000367 & 0.000395 & 0.000583 & 0.000573 & 0.000595 & 0.000378 \\
\hline Storey8 & 0.000649 & 0.000532 & 0.000374 & 0.000408 & 0.000755 & 0.000741 & 0.000762 & 0.000393 \\
\hline Storey7 & 0.000777 & 0.000538 & 0.000372 & 0.000411 & 0.000884 & 0.000867 & 0.00089 & 0.000400 \\
\hline Storey6 & 0.000874 & 0.000529 & 0.00036 & 0.000412 & 0.000975 & 0.000954 & 0.00098 & 0.000402 \\
\hline Storey5 & 0.000935 & 0.000502 & 0.000337 & 0.000415 & 0.001032 & 0.00101 & 0.001037 & 0.000406 \\
\hline Storey4 & 0.000956 & 0.000455 & 0.0003 & 0.000342 & 0.001070 & 0.001038 & 0.001066 & 0.000362 \\
\hline Storey3 & 0.000915 & 0.000389 & 0.00025 & 0.000289 & 0.001063 & 0.001045 & 0.001073 & 0.000287 \\
\hline Storey2 & 0.000762 & 0.000301 & 0.000191 & 0.000223 & 0.001051 & 0.001025 & 0.001054 & 0.000231 \\
\hline Storey1 & 0.000364 & 0.000156 & 0.0001 & 0.000119 & 0.000826 & 0.0008 & 0.000859 & 0.00017 \\
\hline Base & 0 & 0 & 0 & 0 & 0 & 0 & 0 & 0 \\
\hline
\end{tabular}

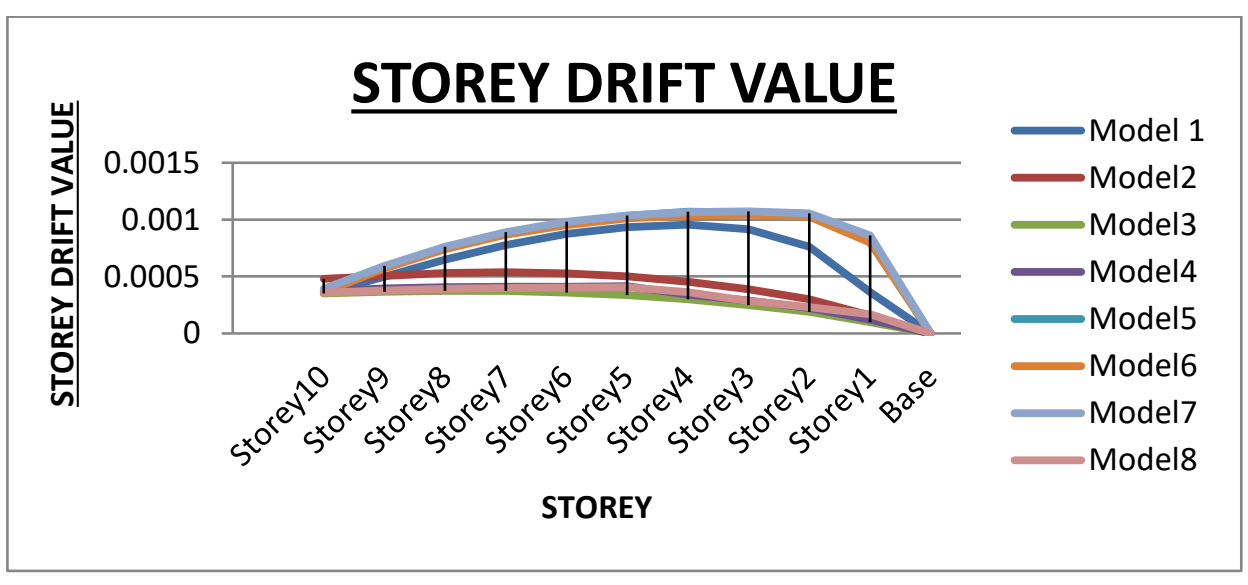

Figure 3. Maximum Storey Drift at different storeys for various models

The highest values of drift occurred at 3rd storey in model-7 and the lowest value at the 1st storey in model-3.

\subsection{STOREY SHEARS}

The values of maximum storey shear obtained for various models, as per IS 1893(part1): 2002, are given in table 5 and shown graphically figure 4.

Table 5. Storey shear $(\mathrm{KN})$

\begin{tabular}{|c|c|c|c|c|c|c|c|c|c|}
\hline Storey & Location & MODEL1 & MODEL2 & MODEL3 & MODEL4 & MODEL5 & MODEL6 & MODEL7 & MODEL8 \\
\hline Storey10 & Top & 679.712 & 1216.1166 & 1280.79 & 1206.65 & 314.68 & 348.432 & 381.77 & 330.241 \\
\hline & Bottom & 679.712 & 1216.1166 & 1280.79 & 1206.65 & 314.68 & 348.432 & 381.77 & 330.241 \\
\hline Storey9 & Top & 1330.53 & 2428.4462 & 2594.65 & 2436.34 & 570.691 & 655.902 & 740.816 & 609.864 \\
\hline & Bottom & 1330.53 & 2428.4462 & 2594.65 & 2436.34 & 570.691 & 655.902 & 740.816 & 609.864 \\
\hline Storey8 & Top & 1844.76 & 3386.3363 & 3632.77 & 3407.94 & 772.972 & 898.841 & 1024.51 & 830.8 \\
\hline & Bottom & 1844.76 & 3386.3363 & 3632.77 & 3407.94 & 772.972 & 898.841 & 1024.51 & 830.8 \\
\hline Storey7 & Top & 2238.46 & 4119.7209 & 4427.58 & 4151.83 & 927.843 & 1084.84 & 1241.71 & 999.954 \\
\hline & Bottom & 2238.46 & 4119.7209 & 4427.58 & 4151.83 & 927.843 & 1084.84 & 1241.71 & 999.954 \\
\hline Storey6 & Top & 2527.71 & 4658.534 & 5011.52 & 4698.35 & 1041.63 & 1221.49 & 1401.28 & 1124.23 \\
\hline & Bottom & 2527.71 & 4658.534 & 5011.52 & 4698.35 & 1041.63 & 1221.49 & 1401.28 & 1124.23 \\
\hline Storey5 & Top & 2728.58 & 5032.7099 & 5417.03 & 5077.89 & 1120.64 & 1316.39 & 1512.1 & 1210.53 \\
\hline & Bottom & 2728.58 & 5032.7099 & 5417.03 & 5077.89 & 1120.64 & 1316.39 & 1512.1 & 1210.53 \\
\hline Storey4 & Top & 2857.14 & 5272.1824 & 5676.56 & 5320.79 & 1171.21 & 1377.13 & 1583.02 & 1265.77 \\
\hline & Bottom & 2857.14 & 5272.1824 & 5676.56 & 5320.79 & 1171.21 & 1377.13 & 1583.02 & 1265.77 \\
\hline Storey3 & Top & 2929.45 & 5406.8857 & 5822.54 & 5457.42 & 1199.66 & 1411.29 & 1622.92 & 1296.84 \\
\hline & Bottom & 2929.45 & 5406.8857 & 5822.54 & 5457.42 & 1199.66 & 1411.29 & 1622.92 & 1296.84 \\
\hline Storey2 & Top & 2961.59 & 5466.7538 & 5887.43 & 5518.15 & 1212.3 & 1426.47 & 1640.65 & 1310.65 \\
\hline & Bottom & 2961.59 & 5466.7538 & 5887.43 & 5518.15 & 1212.3 & 1426.47 & 1640.65 & 1310.65 \\
\hline Storey1 & Top & 2969.63 & 5481.7208 & 5903.65 & 5533.33 & 1215.46 & 1430.27 & 1645.08 & 1314.1 \\
\hline & Bottom & 2969.63 & 5481.7208 & 5903.65 & 5533.33 & 1215.46 & 1430.27 & 1645.08 & 1314.1 \\
\hline Base & Top & 0 & 0 & 0 & 0 & 0 & 0 & 0 & 0 \\
\hline & Bottom & 0 & 0 & 0 & 0 & 0 & 0 & 0 & 0 \\
\hline
\end{tabular}




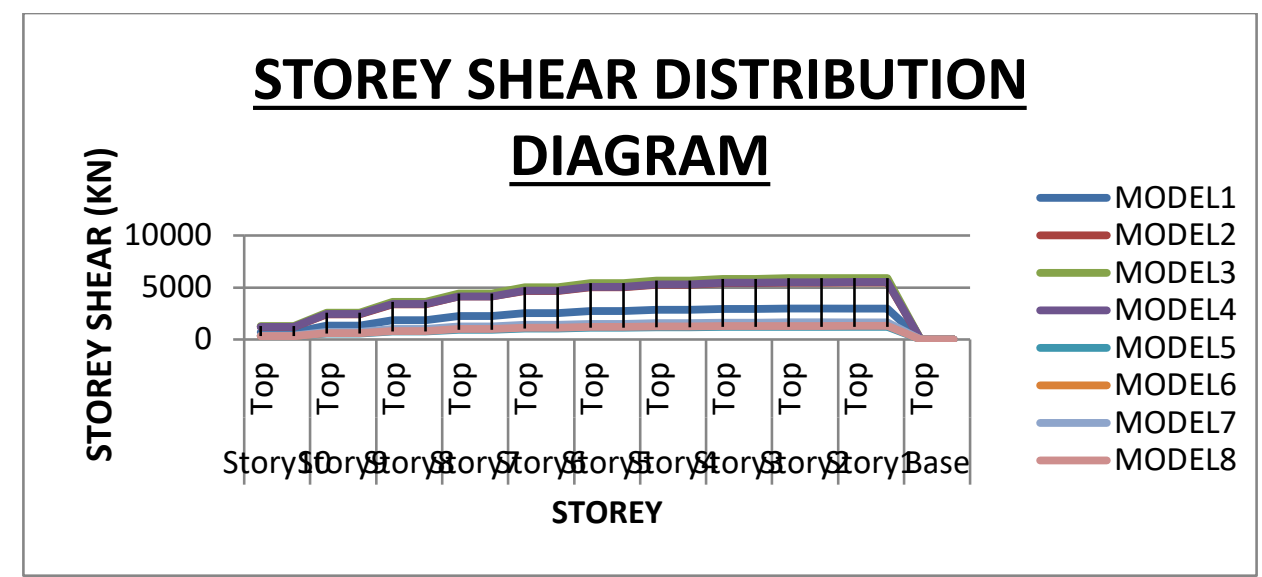

Figure 4. Storey Shear at different storeys for various models

The highest value of storey shear at the 1st storey in model-3 and the lowest value at the 10th storey in model-5.

\subsection{OVERTURNING MOMENTS}

The values of maximum overturning moments obtained for various models, as per IS 1893(part 1): 2002, are given table 6 and shown graphically figure 5 .

Table 6. Overturning moments (KN-m)

\begin{tabular}{|c|c|c|c|c|c|c|c|c|}
\hline Storey & MODEL1 & MODEL2 & MODEL3 & MODEL4 & MODEL5 & MODEL6 & MODEL7 & MODEL8 \\
\hline Storey10 & 0 & 0 & 0 & 0 & 0 & 0 & 0 & 0 \\
\hline Storey9 & 2039.14 & 3648.35 & 3842.36 & 3619.9418 & 944.039 & 1045.3 & 1145.31 & 990.724 \\
\hline Storey8 & 6030.73 & 10933.7 & 11626.3 & 10928.9472 & 2656.11 & 3013 & 3367.76 & 2820.31 \\
\hline Storey7 & 11565 & 21092.7 & 22524.6 & 21152.7682 & 4975.03 & 5709.52 & 6441.28 & 5312.71 \\
\hline Storey6 & 18280.4 & 33451.9 & 35807.3 & 33608.245 & 7758.55 & 8964.05 & 10166.4 & 8312.58 \\
\hline Storey5 & 25863.5 & 47427.5 & 50841.9 & 47703.3057 & 10883.4 & 12628.5 & 14370.3 & 11685.3 \\
\hline Storey4 & 34049.3 & 62525.6 & 67093 & 62936.9662 & 14245.4 & 16577.7 & 18906.6 & 15316.9 \\
\hline Storey3 & 42620.7 & 78342.1 & 84122.7 & 78899.3307 & 17759 & 20709.1 & 23655.6 & 19114.2 \\
\hline Storey2 & 51409 & 94562.8 & 101590 & 95271.5911 & 21358 & 24943 & 28524.4 & 23004.7 \\
\hline Storey1 & 60293.8 & 110963 & 119253 & 111826 & 24994.9 & 29222.4 & 33446.3 & 26936.6 \\
\hline Base & 69202.7 & 127408 & 136964 & 128426 & 28641.2 & 33513.2 & 38381.5 & 30878.9 \\
\hline
\end{tabular}

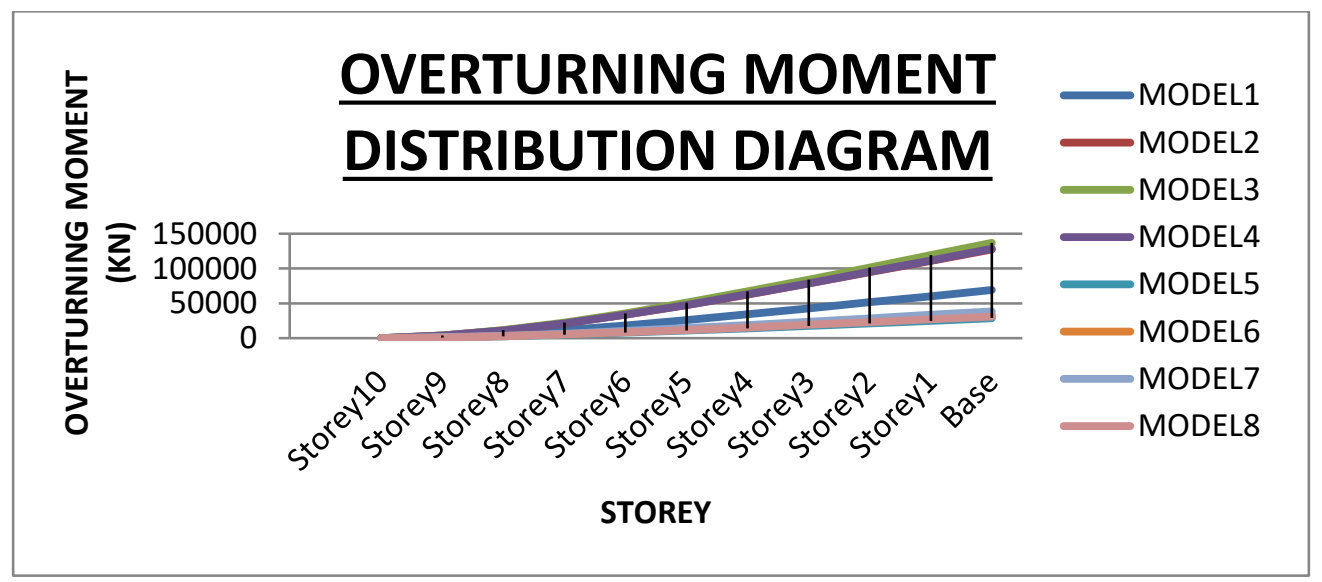

Figure 5. Overturning Moment at different storeys for various models

Comparison of the models, the value of highest overturning moment is at the base in model-3 while the lowest value at the base in model-5. The value of maximum overturning moment decreases with increase in height.

\subsection{Storey Stiffness}

The values of maximum storey stiffness obtained for various models, as per IS 1893(part 1): 2002, are given table 7 and shown graphically figure 6 . 
Table 7. Storey Stiffness (KN/m)

\begin{tabular}{|l|c|c|c|c|c|c|c|c|}
\hline \multicolumn{1}{|c|}{ Storey } & MODEL1 & MODEL2 & MODEL3 & MODEL4 & MODEL5 & MODEL6 & MODEL7 & MODEL8 \\
\hline Storey10 & 322178.9 & 329596.1 & 332595.012 & 647128.9 & 639558.3 & 881041.3 & 1101660 & 1245556 \\
\hline Storey9 & 375357.8 & 393139.1 & 419925.28 & 1020658 & 890550 & 1603579 & 2067826 & 2372875 \\
\hline Storey8 & 389595.4 & 421260.3 & 454527.297 & 1243490 & 948562.8 & 2138608 & 2797246 & 3253574 \\
\hline Storey7 & 396738.9 & 436274 & 472419.336 & 1435918 & 960919.7 & 2568590 & 3383377 & 3982339 \\
\hline Storey6 & 401333.7 & 446609.7 & 484843.069 & 1627437 & 964577.7 & 2952517 & 3912037 & 4655721 \\
\hline Storey5 & 405097.2 & 455624.9 & 495518.152 & 1839425 & 972456.2 & 3360201 & 4477972 & 5388334 \\
\hline Storey4 & 408927.5 & 465284.8 & 506519.868 & 2095096 & 996908.1 & 3883161 & 5206674 & 6338711 \\
\hline Storey3 & 413826.9 & 477508 & 519658.077 & 2426784 & 1067743 & 4682063 & 6325502 & 7798968 \\
\hline Storey2 & 425504.1 & 496227.2 & 538402.522 & 2899211 & 1297464 & 6198207 & 8385944 & 10513960 \\
\hline Storey1 & 555872.2 & 611972.5 & 651917.075 & 4352119 & 2731866 & 12227370 & 16045927 & 20206529 \\
\hline Base & 0 & 0 & 0 & 0 & 0 & 0 & 0 & 0 \\
\hline
\end{tabular}

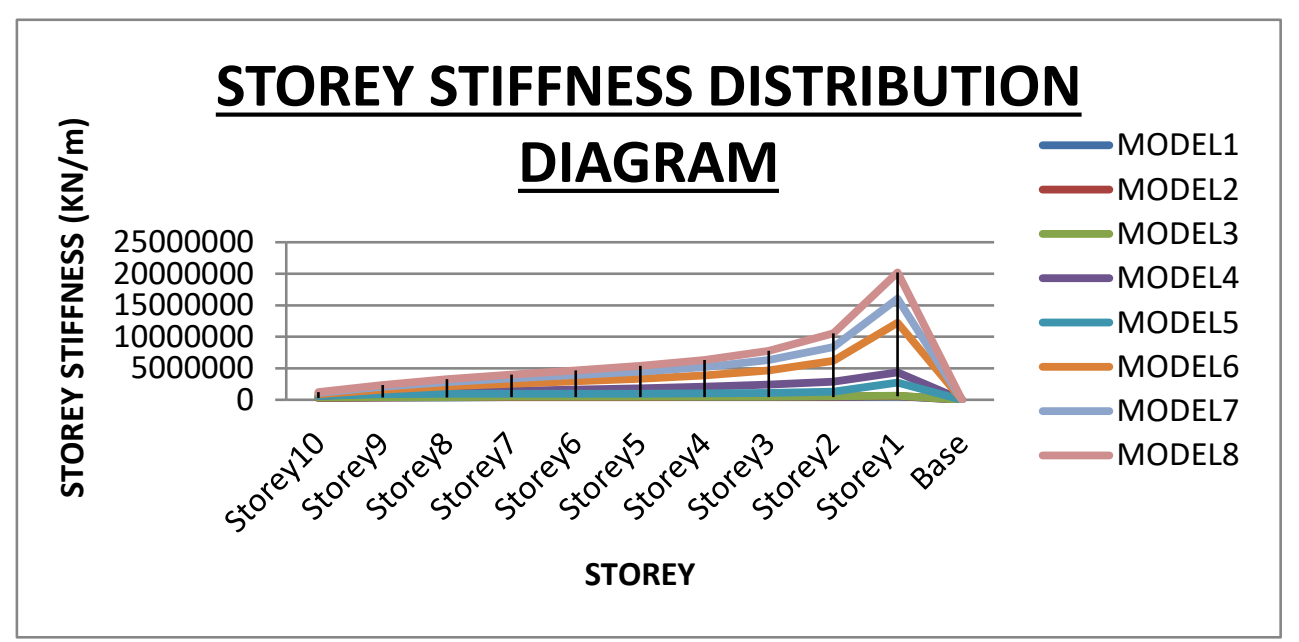

Figure 6. Storey stiffness at different storeys for various models

Comparison of the models, the value of highest storey stiffness is at the first storey in model- 8 while the least value at the storey first in model-1. The value of maximum storey stiffness decreases with increase in height.

\section{SUMMARY AND CONCLUSION}

Total 8-Models of the building were analysed. Model 1 to Model 4 consisted of concrete frame while Model-5 to Model-8 were of steel frame. Model-1 of concrete frame and Model-5 of steel frame were provided with no shear wall. Models 2 to 4 of concrete frame were provided with shear walls on different locations. Shear walls were provided in the models 6 to 8 of steel frame, on the same locations as for models 2 to 4 . The various concrete and steel frame models 1 to 8 were analysed and compared for various parameters through linear static analysis method considering seismic effect.

It has been observed that the values of storey displacement in concrete shear wall are more than steel plate shear walls (SPSW) while the values of storey stiffness in steel plate shear wall are more than concrete shear wall. When compared all 8-models for the best location in the building, the steel plate shear wall (SPSW) provided at the middle (tubular form) and corner of the building has been found the best. It has been concluded that steel plate shear wall system is comparatively more suitable than concrete shear wall system in a building.

\section{REFERENCES}

[1] Peter Timler, Carlos E.Ventura and Reza Anjam (1998), "Experimental and analytical studies of steel plate shear walls as applied to the design of tall buildings", The Structural Design of Tall Buildings, 1998, Volume-7, PP. 233-249.

[2] Astaneh-Asl (2001) "Seismic Behaviour and Design of Steel Shear Walls", SEAONC Seminar, November 2001, San Francisco. PP. 1-18.

[3] Burcu Burak (2013), "Effect of shear wall area to floor area ratio on the seismic behaviour of reinforced concrete buildings" Journal of Structural Engineering, 2013, Volume-139, PP. 1928-1937.

[4] Sumit Pawah (2014), "Steel plate shear wall - a lateral load resisting system" International Journal of Emerging Technology and Advanced Engineering IJETAE,2014, PP. 244- 252

[5] Chandra Shekar and Raj Shekar (2015), "Analysis and design of multi storied building by using Etabs software" International journal of scientific research, 2015, Volume-4, ISSN No. 2277-8179.

[6] R.Resmi and S.Yamini Roja (2016), "A review on performance of shear wall” International Journal of Applied Engineering Research, 2016, Volume-11, ISSN NO. 0973-4562, PP. 369-370. 